\title{
1946 ile 1950 Genel Seçimleri Arasında Denizli’de Siyasi Durum
}

\section{Political Situation in Denizli Between 1946 and 1950 General Elections}

\author{
Dr. Öğr. Üyesi Nermin Zahide AYDIN (iD) 1
}

$\ddot{O} \mathbf{z}$

İkinci Dünya Savaşı'ndan sonra Sovyetler Birliği, Türkiye ile 1945 yılında imzaladığı anlaşmayı kaldırmak istemiştir. Sovyetler Birliği, anlaşmanın yenilenmesi karşıllı̆̆ında yeni bir Boğazlar Sözleşmesi talep etmiştir. Bunun üzerine Türkiye, savaşı kazanan Batı Devletleri ile işbirliği yapmıştır. Çok geçmeden devlet yöneticileri, partilerin kurulması için gerekli ortamı sağlanmıştır. Milli Kalkınma Partisi'nin (MKP) kurulmasından sonra ülkede birçok parti kurulmaya başlamıştır. Öte yandan Cumhuriyet Halk Partisi (CHP) içinde karışıklık çıkmış ve partiden ayrılmalar başlamıştır. CHP'den ayrılanlar Demokrat Parti'yi (DP) kurmuşlardır. DP kurulduktan sonra ülke genelinde hızlı bir şekilde teşkilatlanmaya başlamıștır. DP'nin gelişmesi CHP'nin bazı tedbirler almasına neden olmuştur. Bu amaçla 1947 yılında yapılması gereken seçimler erken bir tarihe alınmıştır. 1946 yılında yapılan genel seçimleri, CHP büyük farkla kazanmıştır. Fakat ilerleyen günlerde taşra teşkilatı içinde yaşanan huzursuzluklar ve diğer partilerin faaliyetleri, bu durumun tersine dönmesine neden olmuştur. Ülke ekonomisinin bozulmasına ek olarak iktidar partisi içinde yaşanan anlaşmazlıkların artması, halkın tercihlerin değişmesine neden olmuştur. Halkın tercihlerinin değiştiği yerleşim yerlerinden birisi de Denizli olmuştur. Bu şartlar altında 1950 yılında yapılan milletvekili seçimleri büyük sürprizle sonuçlanmıştır. Seçim sonunda CHP'nin hiçbir adayı Denizli'de milletvekili seçilememiştir. Çalışmamızda Denizli'de 1946 ile 1950 yıllarında yapılan genel seçimlerde siyasi partilerin mücadeleleri incelenmiştir. Araştırma yapılırken T.C. Cumhurbaşkanlığı Devlet Arşivleri Başkanlığı Cumhuriyet Arşivi'nde bulunan belgeler, dönem gazeteleri ve basılı diğer kaynaklardan yararlanılmıştır.

Anahtar Kelimeler: Denizli, Cumhuriyet Halk Partisi, Demokrat Parti, milletvekili, seçim

Makale Türü: Araştırma

Abstract
After the Second World War, the Soviet Union wanted to remove the agreement signed with Turkey in
1945. The Soviet Union demanded a new Straits Convention in return for the renewal of the
treaty. Thereupon Turkey, collaborated with Western States winning the battle. Before long, state
administrators provided the necessary environment for the establishment of parties. After the establishment
of the National Development Party (MKP), many parties started to be established. On the other hand,
confusion broke out within the Republican People's Party (CHP) and disengagement from the party. Those
who left the CHP formed the Democrat Party (DP). After the DP was established, it started to be organized
rapidly throughout the country. The development of the DP caused the CHP to take some measures. For
this purpose, the elections to be held in 1947 were set to an early date. CHP won the general elections held
in 1946 with a big margin. However, the activities of other parties and the unrest in the provincial
organization caused this situation to reverse in the following days. In addition to the deterioration in the
country's economy, the increase in the conflicts within the government caused to the change preferences of
the people. Denizli was one of the settlements where people's preferences changed. Under these
circumstances, the parliamentary elections held in 1950 resulted in great surprise. At the end of the election,
no candidate of the CHP could be elected as a deputy in Denizli. In our study, the struggles of political
parties in the general elections held in Denizli between 1946 and 1950 were examined. The documents in

${ }^{1}$ Kilis 7 Aralı Üniversitesi, Muallim Rıfat Eğitim Fakültesi, nzahideaydin@hotmail.com.

Atıf için (to cite): Aydın, N. Z. (2020). 1946 İle 1950 genel seçimleri arasında Denizli'de siyasi durum. Afyon Kocatepe Üniversitesi Sosyal Bilimler Dergisi, 22(TBMM'nin 100. Y11ı ve Millî İrade Özel Sayıs1), 116-132. 
the T.C. Documents in the Presidency State Archives Republic Archive, newspapers from the period and other printed sources were utilized in this the process of this study.

Keywords: Denizli, The Republican People's Party, The Democrat Party, deputy, election

Paper Type: Research

\section{Giriş}

Birinci Dünya Savaşı sonrası, Mustafa Kemal Atatürk tarafından Türkiye'nin gelişmesi için birçok alanda yenilikler yapılmış, yapılan yenilikler Türkiye'nin kalkınmasına yardımcı olmuştur. Siyasi anlamda da çok partili demokratik hayata geçmek konusunda önemli adımlar atılmış, fakat istenen başarı elde edilememiştir. Mustafa Kemal Atatürk’ün ölümünden bir süre sonra İkinci Dünya Savaşı'nın çıkması, devlet yöneticilerinin önceliklerinin değişmesine neden olmuş, savaşa girilmemiş bile olsa savaşa hazır halde bekleme mecburiyeti, yöneticilerin çok partili hayata geçiş ile ilgili düşüncelerini ertelemelerini zorunlu hale getirmiştir. Savaş sonrası dönemde Sovyet Hükümeti, Türkiye ile 1925 yılında imzaladığı dostluk anlaşmasının kaldırılacağını duyurmuş, anlaşmanın yenilenmesi karşılığında ise yeni bir Boğazlar sözleşmesi talep edeceğini bildirmiştir. Yapılacak yeni anlaşmayla Sovyet Savaş gemilerine Boğazlardan serbest geçiş hakkı tanınacak, Boğazlarda Sovyet üsleri kurulmasına izin verilecek ve 1921 yılında Türkiye'ye bağlanan Kars ve Ardahan tekrar Sovyet Hükümetine iade edilecekti (Hale, 2003, s.111-112). Ortaya çıkan Sovyet tehdidi, hükümetin iç ve dış politikada farklı manevralar yapmasına neden olmuştur.

Dönemin tek partisi olan CHP'nin karşısında muhalif partilerin kurulması ile çok partili hayata geçiş konusunda önemli adımlar atılmıştır. İlk zamanlarda muhalif partilerin kurulmasına sıcak bakan iktidar, daha sonraki dönemlerde gerek merkezde, gerekse taşrada, muhalif partilerin özellikle DP'nin güçlenmesini önlemek ve kendi örgütünü güçlendirmek için gerekli önlemler almaya başlamıştır. 1946 yılında yapılan genel seçimler, her ne kadar iktidar partisinin başarısı ile sonuçlanmışsa da 1950 yılında yapılan genel seçimler, 1946 yılında yapılan seçimlerin tam aksi doğrultuda bir netice vermiştir.

Taşrada muhalif partilerin teşkilatlanmasının yanı sıra CHP'nin faaliyetlerinin araştırılması, 1946 ve 1950 yıllarında yapılan genel seçimlerde oluşan farkın anlaşılması açısından önemlidir. Yapılan bu çalışma ile Denizli'nin 1946 ile 1950 yıllarında yapılan seçimler arasındaki siyasi durumu araştırılmıştır. Denizli ve diğer vilayetlerdeki siyasi durumun incelenmesi Türkiye'nin o dönem siyasi yapısı hakkında genel bir bakış açısına sahip olunmasını kolaylaştıracaktır. Konu ile ilgili daha önceden yapılmış olup, 1946 ile 1950 seçimlerini ele alan ve ülke genelini kapsayan çalışmalar vardır. Örneğin Süleyman İnan'ın doktora tezi olan Muhalefette Adnan Menderes (1945-1950) isimli çalışmada Adnan Menderes'in çok partili siyasi hayata geçiş sürecindeki yeri, yaptığı muhalefetin parti içindeki etkisi ayrıntılı bir şekilde incelenmiştir. Kenan Olgun tarafından yazılan “Türkiye'de Cumhuriyetin İlanından 1950'ye Genel Seçim Uygulamaları" başlıklı çalışmada Cumhuriyet öncesi dönemden 1950 yılına kadar Türkiye'de yapılan seçim uygulamalarından bahsedilmiştir. Murat Karataş'ın yazmış olduğu “Cumhuriyet Halk Partisi'nin Siyasal İktidar Anlayışı (1946-1950)" isimli çalışmada CHP'nin çok partili siyasi hayata geçişle birlikte parlamentodaki muhalefete tavrı ele alınmıştır. Alper Bakacak tarafından kaleme alınan "1950 Seçimleri Sonrası Ulus Gazetesinin Muhalefete Geçişi”" isimli makalede, CHP'nin yayın organı olan Ulus gazetesinin 1950 seçimlerinden sonraki tutumu incelenmiştir. Çağatay Benhür'ün yazdığı "14 Mayıs 1950 Genel Seçimlerinde CHP ve DP'nin Seçim Kampanyalarının Ana Hatları" başlıklı makalede her iki partinin seçim kampanyalarına dikkat çekilmiştir. Bu ve benzeri çalışmalarda genel olarak Türkiye'de 1946 ve 1950 tarihlerinde yapılan seçimler ele alınmıştır. Bununla birlikte Denizli ile ilgili yapılan çalışmalar da mevcuttur. Süleyman İnan tarafından yazılan "CHP Müfettişi Cemal Karamuğla'nın Raporları Işı̆̆ında Bir Taşra Kenti Olan Denizli’de 1950 Seçimleri ve Gösterdikleri” isimli çalışmada, 1950 
seçimlerinde Denizli'deki milletvekili adaylarının seçim öncesi mücadeleleri ve seçimin Denizli'ye yansımaları ele alınmıştır. Canan Şen'in yazmış olduğu "Demokrat Parti Döneminde Denizli'de Siyasal Hayat (1950-1960)" isimli çalışmada ise 1950-1960 yılları arasında Denizli'de yapılan seçimler araştırılmıştır. Her iki çalışmada arşiv belgelerinden yararlanılmıştır. Fakat yapılan bu çalışmada, yukarıda adı geçen iki çalışmada yer almayan konular ele alınmış, farklı arşiv belgeleri kullanılmış ve iki siyasi parti arasındaki mücadelede CHP'nin başarısız olmasının nedenleri üzerinde durulmuştur.

\section{1. İkinci Dünya Savaşı ve Sonrasında Türkiye}

Türkiye Cumhuriyeti kurulduktan sonra birçok alanda yenilikler yapılmaya başlanmış, devlet kısa süre içinde büyük ölçüde gelişmiştir. Yeniliklerin devamı konusunda 1srarcı olan Mustafa Kemal Atatürk, çok partili demokratik yaşama geçme konusunda da ssrarcı tutumunu sürdürmüş, dönemin tek partisi CHP'nin karşısında 1924 yılında kurulan Terakkiperver Cumhuriyet Fırkasına olumlu yaklaşmıştır (Turgut, 2005, s. 231). Terakkiperver Cumhuriyet Fırkasının kapatılmasından sonra da çok partili demokratik hayata geçme konusunda ısrarını sürdürmüştür. 1930 yılının yaz aylarında Yalova'da kendisini ziyarete gelen Fethi Okyar Bey'e parti kurma konusunda yardımcı olacağını söyleyerek, aynı yıl Serbest Cumhuriyet Fırkasının kurulmasına ön ayak olmuştur (İnan, 2013, s. 376). Serbest Cumhuriyet Fırkası'nın siyasi hayattan çekilmesi ve Mustafa Kemal Atatürk'ün vefatı üzerine yerine İsmet İnönü gelmiştir. İsmet İnönü'nün cumhurbaşkanı olmasından sonra İkinci Dünya Savaşı'nın ortaya çıkması, çok partili siyasal hayata geçme konusunun bir süre ertelenmesine neden olmuştur.

İkinci Dünya Savaşı yıllarında Türkiye'nin dış politikası genel olarak savaşa girmeme konusunda şekillenmiş, fakat siyasi, sosyal ve ekonomik alanlarda büyük sıkıntılar çekilmiştir (Karpat, 2010, s. 202). Savaşa hazır halde bekleme mecburiyeti hükümeti, sadece her sahada kaynak biriktirmeye zorlamamış (Eraslan, 2004, s. 531), aynı zamanda ülkede bazı güvenlik önlemleri almasını da zorunlu hale getirmiştir. Öncelikle güçlü bir ordu oluşturulmaya çalışılmış (Tekeli ve İlkin, 2013, s. 654), ülkenin bombalanması ihtimaline karşı, Genelkurmay Başkanlığ tarafından hazırlanan ve Bakanlar Kurulu'nca onaylanan Hava Taarruzlarına Karșı Ișıkların Söndürülmesi ve Karartılması Hakkında Nizamname hayata geçirilmiştir (Karabulut, 2014, s. 201). Savaş süresince toplumun özellikle işçi ve köylü kesimi ezilmiş, ziraat ve ticaretle uğraşan sermeye sahipleri ise tam aksine büyük ölçüde fayda sağlamışlardır (Eraslan, 2004, s. 531). Kamu yatırımları durmuş, halkın geliri (Oran, 2004, s. 391) ve Türkiye'nin ithalat düzeyi oldukça düşmüştür. Hükümet tahıl karaborsasını önlemek için sıkı tedbirler almış, fakat bu durum köylünün aleyhine olmuştur. Şehirlerde un ve şeker kıtllğı başlamış, ordunun ihtiyacı olan mühimmat, silah, giyim ve kuşam konusunda ciddi anlamda sıkıntılar yaşanmıştır (Ortaylı, 2018, s. 114).

Sıkıntının giderilmesi için hükümet tarafından çeşitli düzenlemeler yapılmıştır. 18 Ocak 1940 yilında yapılan Milli Korunma Kanunu (Eraslan, 2004, s. 532), ekonomiyi güçlendirmek için hükümete olağanüstü durumlarda ürünlere el koyma vb. gibi yetkiler vermiştir. Yine hükümet tarafından ekonomik zorluklarla ve savunma harcamalarıyla mücadele etmek için, 11 Kasım 1942 tarihinde Varlık Vergisi Kanunu çıkarılmıştır. Başlangıçta katı bir şekilde uygulanan bu kanun, yaşanan olumsuzluklar üzerine, 1944 yılında kaldırılmış ama hem Türkiye'nin yurt dışındaki prestijine zarar vermiş (Karpat, 2010, s. 203) hem de halkın önemli bir bölümünün, CHP'ye karş1 tavır almasına neden olmuştur (Oran, 2004, s. 392). Haziran 1943'te kabul edilen Toprak Mahsulleri Vergisi de mevcut şartları istismar edenleri cezalandırmak amacı ile yapılmıştır (Eraslan, 2004, s. 532). Hükümetin bu uygulamaları ise halkın bir bölümünü, önemli ölçüde tedirgin etmiştir (Boratav, 2002, s. 341).

Türkiye, savaş boyunca dış politikada iş birliği, bağımsızlığın korunması ve toprak genişlemesinin reddedilmesi gibi ilkeleri benimsemiş (Karpat, 2010, s. 202), bu nedenle savaştan uzak kalmayı başarmış, fakat savaş sonunda meydana gelen uluslararası politikada yalnız kalmaktan kurtulamamıştır (Koçak, 2009, s. 298). Savaş süresince Türk dış politikasının temel 
hedefi, sınır komşusu olan Sovyetler Birliği ile ilişkisini bozmadan, ülkenin güvenliğini sağlamak olmuştur (Aydın, 2004, s. 475). Cumhurbaşkanı İnönü, 1 Kasım 1942 tarihinde TBMM’yi açış konuşmasında Türkiye'nin o günkü durumu ile ilgili olarak "Bir gün bilmediğimiz bir istikametten ve bilmediğimiz bahaneler altında vatanımızın taarruza maruz kalması ihtimalini, Büyük Millet Meclisi'nin göz önünde tutması icap eder" demiştir (Koçak, 2015, s. 713). Fakat Sovyetler Birliği ile kurulan ilişkiler, savaş sonunda bozulmaya başlamıştır. Sovyetler Birliği, Türkiye ile imzaladığı ve süresi 1945 yılında dolacak olan dostluk anlaşmasını yenilemeyeceğini açıkladığı gibi, iki ülke arasındaki sınırın düzeltilmesini ve Karadeniz'in korunması için İstanbul Boğazı ile Çanakkale Boğazı bölgesinde müşterek bir Türk-Sovyet savunma gücünün kurulmasını istemiştir (Zürcher, 2015, s. 306-307). Dönem gazetelerinde yer alan haberlere göre bütün bunlara ek olarak Sovyetler, daha demokrat bir Türk hükümetinin kurulmasını istediklerini belirtmişlerdir (Sovyetlerin Talepleri, Cumhuriyet, 29 Haziran 1945, s.1). Savaş sonrası dönemde Sovyetlerin taleplerinde 1srarcı olması, Türk hükümetinin çok partili sistemlerle ve demokratik anlayışla yönetilen devletler (Eraslan, 2004, s. 533), özellikle de Batı Devletleri ve Amerika Birleşik Devletleri ile iş birliği içinde olmasına neden olmuştur (Zürcher, 2015, s. 306).

1945 ’te Türk hükümetinin, San Francisco Konferansı'na kurucu üye olarak katılıp, Birleşmiş Milletler Anlaşmasını imzalaması, ülke içinde demokratik adımlar atılmasını hızlandırmıştır (Zürcher, 2015, s. 306). Konferansta Amerika Birleşik Devletleri'ne, Rus tehdidinden bahsedilmiş, fakat ilk zamanlarda beklenen karşılık bulunamamıştır. 1945 ve 1946 yıllarında tek başına kalan Türkiye, Rus baskılarına karşı mukavemet etmiş, Amerikan yardımı ancak 1947 yılında gelmiştir (Tellal, 2004, s. 508). Diğer taraftan Cumhurbaşkanı İnönü, 19 Mayıs Spor Bayramı'nda yaptığı konuşmasında siyasi hayatta demokratik prensiplerin büyük ölçüde yer alacağının sinyallerini vermiştir (Lewis, 2000, s. 303). Türk hükümeti, çok partili siyasi hayata geçme konusunda kararlı olduğunu, San Francisco Konferansına gönderdiği temsilcisi ile müttefiklerine duyurmuş (Eraslan, 2004, s.533) ve tek parti idaresinin sona ermesine neden olan sürecin başlamasına neden olmuştur (Lewis, 2000, s. 303).

\subsection{DP'nin Kurulması}

Savaş koşullarında uygulanan korumacı ekonomik politikalar, 1946-1950 döneminin gelişmelerinde büyük ölçüde etkili olmuştur. Hükümetin, memurunu hayat pahalılığına karşı koruma çabası, işçi ve köylülerin siyasi tercihlerinin değişmesine neden olmuştur (Eraslan, 2004, s. 532). Dönemin tek partisi olan CHP içinde ise fikir ayrılıkları savaş sonrası dönemde belirgin hale gelmiş, fikir ayrılıkları 1945 yılı Ocak ayında TBMM'de tartışılan toprak reformu tasarısı ile iyice açığa çıkmıştır. 14 Mayıs 1945 tarihinde Meclis'e sunulan toprak reformu tasarısına, toprak sahipleri ve taşradaki bazı tüccar gruplarından oluşan bir grup milletvekili muhalefet etmiştir. Toprak Kanunu, CHP içinde derin bir sosyal ve siyasal ayrilığa neden olup, taşrada muhalefet oluşumunu teşvik etmiştir (Karpat, 2010, s. 205-206).

1945 yılından sonra başlayan siyasi mücadele, iktidarı elinde bulunduran CHP'ye karşı yapılmıştır. CHP'ye karşı muhalefet resmen 1945 yılında toprak reformu üzerine yaşanan bir tartışma sırasında kendi içinde doğmuş (Karpat, 2009, s. 231), DP'nin kurulması da doğrudan doğruya bu toprak reformu tartışmaları ile ilgili olmuştur (İnalcık, 2009, s. 373). Nitekim 7 Haziran 1945 tarihinde Celal Bayar, Adnan Menderes, Fuat Köprülü ve Refik Koraltan, devlet mekanizmasının işleyişinde demokratikleşmeyi esas alan bir önergeyi parti meclis grubuna vermişlerdir (Eraslan, 2004, s. 533). Dörtlü Takrir olarak bilinen bu önerge, savaş sonrasındaki örgütlü siyasal muhalefetin başlangıç simgesi haline gelmiştir. Dörtlü Takrir'in sunuluşundan bir hafta sonra İstanbul'da ara seçimler yapıldığında, hükümet ilk kez CHP'nin çeşitli adayları arasında tercih yapılmasına izin vermiştir (Zürcher, 2015, s. 310). Bu arada Haziran 1945 tarihinde yeni bir demokrat parti kurulacağına dair gazetelerde haberler yer almaya başlamış (Yeni Parti, Cumhuriyet, 2 Haziran 1945, s.1), 7 Temmuz 1945 tarihinde ise sanayici Nuri Demirağ, MKP'yi kurmak için İçişleri Bakanlığına başvurmuştur (Eraslan, 2004, s. 533). Nuri Demirağ'ın MKP'yi kurmasıyla da çok partili siyasal hayata yönelik ilk adım atılmışırı (Tekeli ve İlkin, 2013, s. 631). 
Öte yandan Dörtlü Takrir sahiplerinden Fuat Köprülü ve Adnan Menderes'in Tan ve Vatan gibi muhalif basın organlarında eleştirilerini sürdürmeleri, parti disiplinini ihlal olarak değerlendirilmiş ve adı geçen kişiler, 21 Eylül 1945 tarihinde partiden ihraç edilmişlerdir (Eraslan, 2004, s. 534). Parti içinde bu gelişmeler yaşanırken, Cumhurbaşkanı İnönü 1 Kasım 1945 tarihinde, Meclis'in yeni toplantısını açış konuşmasında, Türkiye'nin bir diktatörlük olmadığını, fakat bir muhalefet partisinden yoksun olduğunu söylemiştir (Lewis, 2000, s. 305). Çok geçmeden Refik Koraltan, Vatan gazetesinde Menderes ve Köprülü' yü savunan bir makale yazmış, CHP grubu 27 Kasım tarihinde 1 oya karş1 280 oy ile Koraltan'ın da partiden çıkarılmasına karar vermiştir (Lewis, 2000, s. 304). 3 Aralık 1945 tarihinde Celal Bayar, DP'yi kurmak için CHP'den istifa etmiştir (Tekeli ve İlkin, 2013, s. 632).

7 Ocak 1946 tarihinde Celal Bayar, Adnan Menderes, Fuat Köprülü ve Refik Koraltan tarafından kurulan DP'nin genel başkanlığına Celal Bayar getirilmiştir. Partinin siyasi amacı, ülkede demokrasinin geniş ve ileri ölçüde gerçekleşmesini sağlamak olmuştur (Koçak, 2002, s. 181). DP'nin kurulması ile birlikte, liberal tepki ile belirlenen çok partili dönem belirgin hale gelmiştir (İnalcık, 2009, s. 352).

1930 ve 1945 yılları arasında uygulanan politikalardan bunalan kentli alt tabaka mensupları, işçiler ve köylüler liberalleşmiş bir ekonomik rejimi destekledikleri için (Karpat, 2009, s. 232), DP kurulduktan altı ay sonra üye sayısı bir milyona ulaşmıştır. İşçi ve köylülerin yanı sıra orta sınıf ve diğer memnuniyetsiz olan gruplar da partiyi desteklemişlerdir (Karpat, 2010, s. 207). DP'nin kurulmasıyla Cumhurbaşkanı İnönü'nün muhalefet isteği yerine gelmiş, partinin çalışmalarında kolaylık gösterilmiş (Lewis, 2000, s. 305), yeni parti, hükümet ve yönetimi denetleyecek yeni bir denetim organı olarak görülmüştür (Koçak, 2002, s. 181). DP, şubelerini açmaya başlar başlamaz, bütün ülkede coşkulu bir karşılık bulmuş, bunun üzerine Mayıs 1946 yılında yapılan CHP olağanüstü kongresinde önlem amaçlı bazı kararlar alınmıştır (Zürcher, 2015, s. 310).

\subsection{Genel Seçimleri}

CHP ikinci olağanüstü kurultayı, 10 Mayıs 1946 tarihinde Ankara'da, CHP'nin yapısında çok partili hayata uyum sağlayacak bazı değişiklikleri gerçekleştirmek amacı ile toplanmıştır (Koçak, 2002, s. 181). Kurultaydan önce CHP Meclis Grubu, 1947 genel seçimlerinin bir yıl öne alınarak, 21 Temmuz 1946 tarihinde, belediye seçimlerinin ise hemen yapılmasına karar vermiştir. Bunun üzerine DP, seçimleri boykot etmek istemiş (Lewis, 2000, s. 305), 21 Nisan tarihinde milletvekili ara seçimlerine ve 26 Mayıs tarihinde belediye seçimlerine katılmamıştır (Koçak, 2002, s. 182). DP Genel Başkanı Celal Bayar, DP'nin 1947 yılındaki kongresinde yaptığ 1 konuşmasında CHP'nin, DP'nin gelişmesine meydan vermemek için seçimleri bir yıl önceye aldığını iddia etmiştir (Demokrat Parti Kongresi, Vakit, 8 Ocak 1947). DP'nin mahalli seçimleri boykot etmesinden sonra ise seçimlere yönelik düzenlemeler hızlandırılmıştır. DP'nin ısrarla savunduğu tek dereceli seçim sisteminin kabul edilmesi üzerine, erken genel seçimleri boykot edeceğini açıklayan DP, seçimlere girme kararı almıştır (Eraslan, 2004, s. 538). 5 Haziran tarihinde milletvekili seçimlerinin tek dereceli olarak kabul edilmesine rağmen, seçim sistemi çoğunluk sistemi olarak kalmış, gizli oy, açık sayım ilkesi ile seçimin adli denetim altında yapılması gibi muhalefetin bazı talepleri iktidar tarafından reddedilmiştir (Koçak, 2002, s.182).

1946 genel seçimi, son yasal düzenleme uyarınca adli denetim dışında açık oy, gizli sayım ilkesine ve çoğunluk sistemine göre yapılmıştır. (Koçak, 2002, s. 182). Seçime CHP, DP ve MKP (Ortaylı, 2018, s. 117) ve diğer bazı küçük partiler katılmıştır (Koçak, 2002, s. 183). CHP listesinde yer alan yeni milletvekili adaylarının çoğu devlet hizmetinde ve parti örgütlerinde önemli görevlerde bulunan kişilerden oluşmuştur. 1946 yılında yapılan seçimlerde Denizli’de seçime katılmayan DP, aday listesini daha ziyade serbest meslek kökenli olanlardan oluşturmuştur (Koçak, 2009, s. 527). 
Cumhuriyet tarihinin ilk tek dereceli milletvekili seçimi, 21 Temmuz günü yapılmış (Koçak, 2009, s. 528), seçimler sonunda CHP 395, DP 66 ve bağımsızlar da 4 milletvekilliği kazanmışlardır (Koçak, 2002, s. 183). Ancak seçim sonuçlarının ilanı ile birlikte DP, CHP ve yönetimi, seçimlere hile ve baskı karıştırdığı gerekçesi ile suçlamıştır. Meclisin açılması ile birlikte DP, seçim ile ilgili itirazda bulunmuş, Mecliste itirazları incelemek üzere bir komisyon kurulduysa da komisyon hiçbir itirazı yerinde görmemiştir (Koçak, 2002, s. 183). DP’nin milletvekilliği kazandığı iller Afyon, Bilecik, Bolu, Burdur, Çanakkale, Edirne, İçel, İstanbul, Kayseri, Kastamonu, Muğla ve Sinop olmuştur (Koçak, 2009, s. 529).

\subsection{Parti Mücadeleleri}

CHP'li ve DP'liler arasındaki ilişkiler, 1946 yılında yapılan genel seçimlerden sonra gittikçe kötüleşmeye başlamıştır. Bu arada DP'nin birinci büyük kongresinin, 7 Ocak 1947 tarihinde Ankara'da toplanmasına karar verilmiştir. Kongrede seçim kanununun tadili hakkında görüşmeler yapılacağı ile ilgili, basında haberler yer almıştır (Demokrat Parti Kongresinde Neler Görüşülecek, Vakit, 4 Ocak 1947, s.3). 7 Ocak tarihinde açılan kongrede bir konuşma yapan DP Genel Başkanı Celal Bayar, tek parti yönetiminin zarar ve aksak yönlerinden bahsetmiştir. Kongrede Bayar'ın ortaya koyduğu ana sorunların görüşülmesi için bir komisyon kurulmuş, parti içinde konu ile ilgili iki farklı görüş ortaya çıkmıştır. Kongrede sertlik yanlıları ile 1lımlı kanat arasında bir anlaşma sağlanmış ve "Hürriyet Misakı" adı verilen bildiri kabul edilmiştir (Koçak, 2002, s. 184).

Ülke genelinde iki siyasi partinin kıyasıya mücadelesi gerginliği tırmandırmış, Cumhurbaşkanı İnönü, Haziran 1947'de iki partinin temsilcileri ile ayrı ayrı görüşerek, 12 Temmuz Bildirisini yayınlamıştır (Lewis, 2000, s. 306). İnönü, bildirisinde son zamanlarda hükümet ve muhalefet başkanları ile yaptığı görüşmeleri anlatmış, iktidar ve muhalefet arasında bir diyalog kurulması için harcadığı çabaları açıklamıştır (Koçak, 2002, s. 185). Fakat beyannamenin yayınlanmasından sonra antidemokratik kanunların değiştirilmemesi ve oy serbestliğinin konu edildiği seçim kanununun yapılmaması, beyannamenin bir oyalama taktiği şeklinde algılanmasına neden olmuştur (Demokratlar Gittikçe Sabırsılanıyor, Cumhuriyet, 6 Ocak 1948, s. 3). 12 Temmuz bildirisi, partililer tarafından genel olarak olumlu karşılansa da gerek CHP, gerekse DP içinde önemli tartışmalara neden olmuş, her iki partideki çatışmaları ve bölünmeleri de beraberinde getirmiştir (Koçak, 2002, s. 186).

Yaşanan gelişmeler üzerine CHP, kendisini demokratik hayatın gereklerine uyarlamaya çalışmıştır (Karpat, 2010, s. 208). CHP'nin iktidarda iken yaptığı son kurultayı, 17 Kasım 1947 tarihinde Ankara'da toplanmıştır (Koçak, 2002, s. 188). Seçimleri kazanmak için, halkın durumu hakkında birinci elden edinilen bilgilerin önemini fark eden yöneticiler, ilk defa bu kurultayda partinin kırsal bölgedeki delegelerin görüşlerine yakın ilgi göstermiştir (Karpat, 2010, s. 208). Kurultayda, CHP'nin geleneksel bürokratik ve otoriter yapısı kırılmak istenmiş, parti içi siyasal mekanizmaların çok partili hayata uyum sağlanmasına çalışılmıştır (Koçak, 2002, s. 189). Öte yandan hükümete ve CHP'ye karş1, DP tarafından yoğun eleştiriler yapılmaya başlanmıştır. DP'nin kurucularından Refik Koraltan, tepkisini demokrasinin bazı çevreler tarafından hala tek partili demokrasi zannedildiği, milletvekili ve belediye seçim kanunlarının hızlı bir şekilde demokratik şekle dönüştürülmesi gerektiğini söyleyerek belirtmiştir (Hükümetle Halk Partisi Arasında İhtilaf mı Var? Cumhuriyet, 7 Ocak 1948, s.4).

CHP Meclis Grubunun yaptığı toplantıda, seçim kanununun tadili için prensip kararı alması, DP tarafından olumlu bir adım olarak görülse de (Muhalefet H. Partisinin Kararından Memnun, Cumhuriyet, 15 Ocak 1948, s. 1), Celal Bayar demokrasi temellerinin atılmasına izin verilmediği takdirde Meclisten çekileceklerini ifade etmiştir (Nutkun Metni, Cumhuriyet, 18 Ocak 1948, s.1). Çok geçmeden DP temsilcileri, genel seçimlerin 1949 yılı başında yapılmasını istemişler (Demokratlar ve Genel Seçim, Gece Postası, 22 Ağustos 1948, s. 1), bu isteklerini Adapazarı mitinginde iktidar partisini eleştirerek yinelemişlerdir (Demokrat Partinin Adapazarı Mitinginde, Son Posta, 4 Ekim 1948, s. 7). Fakat DP'nin sürekli olarak genel seçimlerin erkene 
alınması isteği, iktidar partisi tarafından olumlu karşılanmamıştır (Başbakan Diyor ki, 1950'den Evvel Yeni Seçim Yapılmayacak, Akşam, 4 Nisan 1948, s. 2).

Kısa bir süre sonra DP içinde karışıklık çıkmış (DP'deki Anlaşmazlıklar, Yeni Sabah, 10 Şubat 1948, s.1), küçük bir grup 1948'de partiden ayrılarak, Millet Partisi'ni (MP) kurmak için hazırlıklara başlamıştır (Karpat, 2010, s. 208). Program ve tüzüğünü hazırlayan MP (Millet Partisi Program ve Tüzüğünü Hazırladı, Son Telgraf, 5 Temmuz 1948, s. 1), 20 Temmuz 1948 tarihinde kurulmuş ve CHP'nin bazı hoşnutsuz üyelerinin desteğini toplamıştır. DP'de yaşanan bu ayrılmalar, DP'nin Meclisteki milletvekili sayısının önemli ölçüde düşmesine neden olmuştur (Lewis, 2000, s. 307). Öte yandan 1948 yılında yapılacak ara seçimlere katılmayacağını açıklayan DP yetkilileri, büyük çoğunluğun ara seçimlere katılmadığı takdirde seçim kanununun değişebileceğini ve genel seçimlerin bir an evvel yapılabileceğini açıklamışlardır (DP Seçime Girseydi Milli İradenin Tecellisini Geciktirirdi, Son Posta, 10 Ekim 1948, s. 1). 1948 yılında yapılan ara seçimlere DP katılmazken, bağımsız adayları desteklemekten geri kalmamıştır (Eraslan, 2004, s. 543). DP'nin katılmadığ 1 ara seçimlerde CHP'li bütün adaylar, milletvekili olarak seçilmişlerdir (Seçim Bölgelerindeki Muhabirlerimizin Telgrafları, Son Posta, 18 Ekim 1948, s. 7). Seçimden sonra bir açıklama yapan Celal Bayar, hükümetin hemen genel seçimleri yapması gerektiğini söylemiştir (İktidara Düşen İlk Vazife Umumi Seçime Gitmektir, Son Posta, 22 Ekim 1948, s. 7). Yurt gezilerinde ise sık sık ilk hedeflerinin dürüst bir seçim yapılmasının sağlanması (İlk Hedef Namuslu Bir Seçimdir, Son Posta, 9 Aralık 1948, s. 1) ve seçimlerin emniyet altına alınması olduğunu belirtmiştir (Bizim İçin Esas Seçimlerin Emniyet Altına Alınmasidır, Son Posta, 13 Aralık 1948, s. 1).

Ekonomik sıkıntıların yaşandığı bu dönemde, halkın memnuniyetini arttırmak için, CHP yönetimi tarafından birtakım girişimlerde bulunulmuştur. CHP Parti Genel İdare Kurulu, hayat pahalılığının önlenmesi için yapılacak işleri görüşmek üzere bir toplantı yapmış (Hayat Pahalılığı ve CHP, Cumhuriyet, 9 Ocak 1948, s. 1), hiçbir münhale memur tayin edilmemesi için vilayetleri bilgilendirmiştir (Memur Kadroları İçin Mühim Bir Tamim, Cumhuriyet, 9 Ocak 1948, s. 1). Yine dairelerde vatandaşlara zorluk çıkarılmaması yönünde kararlar alınmış (İdari Zihniyet Değişiyor, Tan, 9 Mart 1949, s. 1), hayat pahalılı̆̆ını önlemek için bazı tedbirlere ihtiyaç duyulmuştur (Hayat Pahalılığına Karşı Cezri Tedbirler Alınıyor, Tan, 17 Nisan 1949, s. 1). Fakat bütün bunlara rağmen DP İstanbul İl İdare Kurulu tarafindan hayat pahalılığını ve geçim zorluğunu protesto eden bir miting düzenlenmiştir (Pahalılık Mitingi Dün Sabah Yapıldı, Tan, 9 Mayıs 1949, s. 1).

Bu gelişmeler yaşanırken DP'li yöneticiler, yurt gezilerine ve kendilerini halka anlatmaya devam etmişlerdir. DP Başkanı Celal Bayar, Antalya ziyaretinde üç seneden beri sürdürdükleri hürriyet ve hak mücadelelerinin ilerlediğini ve sonucunu çok yakında alacaklarını söylemiştir (C. Bayar Antalya'da, Tan, 6 Mart 1949, s. 7). DP yönetimi, iktidarın kendi taleplerini yerine getirme konusunda sergilediği tavırdan rahatsızlık duymuş, ilişkiler tekrar gerilmiştir. 20 Haziran 1949 tarihindeki ikinci kurultayda bazı kararlar alınmıştır (Eraslan, 2004, s. 544). Kongrede, parti içinde baş gösteren anlaşmazlıklar, çatışmalar ve ihraçlar sorunu gündeme gelmiş, seçimlere yaklaşıldı ğı bu dönemde partinin izlemesi gereken siyaset belirlenmiştir (Koçak, 2002, s. 191).

İki parti arasında tırmanan gerilimin en büyük nedenlerinden biri olan seçim yasası, muhalefetin baskısı ile birkaç kez değiştirilmiştir (Zürcher, 2015, s. 314). Nihayet tek dereceli, genel, eşit ve gizli oy açık tasnif ilkelerine dayanan ve çoğunluk sistemini getiren seçim kanunu (Eraslan, 2004, s. 545) 16 Şubat 1950 tarihinde, 341 kabul, 10 ret oyu ile kabul edilmiştir (Ortayl,, 2018, s. 117). 16 Şubat 1950 tarihinde TBMM'de kabul edilen seçim yasasına göre tek dereceli genel, eşit ve gizli oyla serbest seçim yapılması, sandık kurullarında siyasal parti temsilcilerinin bulunabilmesi, gizli oy açık sayım ilkesinin uygulanması ve seçimlerin adli denetim altında yapılması sağlanmıştır. Hükümet yeni seçimlerin 14 Mayıs tarihinde yapılacağını ilan etmiştir (Koçak, 2002, s. 192). 


\section{Denizli Halkının Sorunları}

15 Aralık 1945 tarihinde CHP Genel Sekreterliği'nden gönderilen yazıda, Denizli milletvekillerinden Denizli ilinin ilçe, bucak ve köylerini gezip halk ile görüșerek, halkın dileklerinin ilgili bakanlıklara bildirmeleri istenmiştir. Denizli, dokumacılık alanında Türkiye'nin başta gelen bölgesi olduğu için halkın çoğu Ege Bölgesinde kurulması düşünülen iplik ve iplik boya fabrikasının Denizli'de kurulmasını, tezgâhlarda çalışan insanlar ise işlerinde usta oldukları ve işlerini çabuk bitirdikleri için tezgâh başına verilen iplik miktarının arttırılmasını talep etmişlerdir. Bütün bunlara ilaveten, Denizli'den Aydın istikametine gönderilen unların sevkiyatında nakliye masrafının azaltılması için trenden faydalanılması, Denizli merkezde ve ilçelerinde kira ile tutulan evlerde hizmet gören Ziraat Bankası şubeleri için bina yaptırılması, eşya nakliyatı için kaza ile nahiye belediyelerine ve un fabrikalarına kamyon verilmesi de diğer talepler arasında yer almıştır. Çivril'de yarım kalan Işıtlı Barajının tamamlanması, Acıpayam bataklığının kurutulması, Sarayköy ovasının sulanması için sulama kanallarının bitirilmesi, Tavas ilçesinin Solmaz ve Medet köylerinden çıkan iki suyun Tavas ovasında birleşerek oluşturdukları bataklığın önlenmesi, Acıpayam ilçesinin Kızılhisar bucağının su ihtiyacını gidermek için bucağa $15 \mathrm{~km}$ yakında olan akarsuyun sularının su yolları ve kanallar yapılarak bucağa getirilmesi de istenmiştir. Yine Denizli halkı merkeze tabi olan Koncalı istasyonu civarındaki bataklığın kurutulmasını, Buldan kazasının güney boğazından gelen Menderes nehrinin önüne küçük bir baraj yapılmasını, Tavas ilçesinin Hırka köyünün su ihtiyacının karşılanmasını, hayvancılığının geliştirilmesini, yonca ve diğer hayvan yemi tohumluklarının verilmesini, Çal ve Buldan ilçelerinde bağcılığın geliştirilmesini talep etmişlerdir (BCA, 490.1.0.0/641.123.1,14.01.1946, s. $1-6)$.

1947 yılında iki parti arasında gerginlik tırmanırken, Denizli'de yaşanan ekonomik sıkıntıların artarak devam etmesi, halkın tercihlerinin şekillenmesinde önemli bir faktör olmuştur. Denizli milletvekili Cemil Çalgüner tarafindan 21 Nisan 1947 tarihinde verilen sözlü soru önergesinde Denizli'de bazı mahsullerin dondan büyük miktarda zarar gördügü ve bu zararın giderilmesi için hükümetin ne gibi önlemler aldığı sorulmuştur (BCA, 30.1.0.0/53.314.5,21.04.1947, s. 2). Denizli halk1 ise mevcut sıkıntılarının giderilmesi için hükümetten bazı taleplerde bulunmaya devam etmişlerdir. Denizli'nin suyunun bol olmasına rağmen içme suyunun yetersiz oluşu, belediyenin içme suyu projesini yeni hazırlamış olması ve önceden yapılan imar planının yerine getirilemeyişi halkın sıkıntıya girmesine neden olmuştur (Denizli, Tan, 12 Mayıs 1949, s. 4). Özellikle Acıpayam'da yaşayanlar, belediyenin çalışmamasından şikâyetçi olmuşlardır (Acıpayamın Dertleri, Tan, 5 Haziran 1949, s. 4). Tavas halk1 ise, mahsullerini satmak için Denizli'ye kadar gittiklerini ve orada günlerce bekleyerek masraf ettiklerini belirtmişler, bu nedenle Tavas'ta bulunan ofis ambarında ve Ziraat Bankası şubesinde yerinde satış yapmalarına izin verilmesini istemişlerdir (BCA, 490.1.0.0/1575.416.1, 08.07.1947, s. 11). Kale nahiyesinde yaşayanlar susuzluk, yer darlığ sık sık dizanteri hatta tüberküloz salgını ile karşı karşıya kaldıklarını dile getirmişler, bunun önlenmesi için kasabanın nakledilmesi ile ilgili olarak gerekli ricalarda bulunmuşlardır. Fakat bu istekler, yetkililer tarafından fazla ciddiye alınmamıştır (BCA, 490.1.0.0/1575.416.1, 08.07.1947, s. 12). Sarayköylüler de halen istimlak muamelesi tamamlanamayan çiftlik meselesinin çözümlenmesi talebinde bulunmuşlardır (BCA, 490.1.0.0/1575.416.1, 08.07.1947, s.26). Yine Tavas'a $10 \mathrm{~km}$ mesafede bulunan Kızılcabölük nahiyesinin iki kilometre eksik kalan yolunun yapılması da diğer istekler arasında yer almıştır (BCA, 490.1.0.0/151.599.2,22.03.1948, s. 9798).

\section{Denizli'de DP'nin Siyasi Yapılanması}

1946 seçimlerinden önce nüfus sayısına göre illerin ne kadar milletvekili çıkaracakları tespit edilmiştir. 1946 yılında Denizli’nin nüfusu yaklaşık 315 bin kişi olduğu (Şen, 2019, s. 56), seçmen sayısının ise yüz kırk sekiz bin dört yüz otuz iki olup, sekiz milletvekili çıkarması gerektiği CHP Genel Sekreterliğine bir telgrafla bildirilmiştir (BCA, 490.1.0.0/365.1534.2,23.07.1949, s. 10). 1946 genel seçimleri sonunda Denizli'de bir tanesi 
bağımsız olmak üzere sekiz milletvekili seçilmiştir. Bağımsız milletvekili Reşat Aydınlı olup diğer seçilen milletvekilleri ise CHP adaylarından oluşmuştur. Bunlar Mustafa Hamdi Berkman, Mehmet Cemil Çalgüner, Mehmet Abidin Ege, Mustafa Naili Küçüka, Mehmet Hulusi Oral, Mehmet Kemal Öncel ve Ömer Behçet Uz'dur (TBMM Albümü, 2010, s. 461-462; Şen, 2019, s. 56). CHP'nin Denizli' de aldığı oy oranı (yurt dışı oyların da eklenmesi ile) \% 87,5 Bağımsızların aldığ1 oy oranı ise \% 12,5 olarak gerçekleşmiştir (https://www.yenisafak.com-1946/denizli-ilisecimsonuclari).

Seçim sonunda CHP, ülke genelinde büyük bir başarıya imza atmış olsa da, teşkilatlardaki anlaşmazlıklar devam etmiştir. Örneğin Denizli'de Fahri Uzel, 2 Ağustos 1946 tarihinde CHP Genel Sekreterliğine gönderdiği yazıda yeni yapılan milletvekili seçimi ile ilgili bir ihbarda bulunmuştur. Uzel yazısında, Çal CHP İdare Heyeti Başkanı Ömer Özgen'in oy pusulalarından Fahri Akçakoca ile Abidin Ege'nin isimlerinin çizilerek yerlerine müstakil adaylardan Orhan Vural ve Ziya Gökalp'in yazılmasını seçim bürolarında görevli memur ve parti müşahitlerine tembih ettiğini belirtmiştir. Fahri Uzel, Özgen'in amacının bu adayların parti nüfuzu ile korunmasını sağlamak ve ilçede kurdukları şebeke ile daima partide iş başında kalmak olduğunu, fakat bu durumun partiyi kötü duruma düşüreceğini belirtmiştir (BCA, 490.1.0.0/151.599.2,22.03.1948, s. 24).

Denizli'de bu dönemde genel olarak mevcut şikâyetlerin giderilmesi için olumlu sayılabilecek girişimlerde bulunulmuştur. Bazı partililerin bulundukları muhitte birçok kamu hizmetini yürütmeye çalışmaları, hem işlerin iyi yapılmamasına hem de yeni elemanların yetişmesine engel olmuştur (BCA, 490.1.0.0/365.1534.2,23.07.1949, s. 1-9). Bu olumsuzluğu önlemek için, parti içinde önemli kararlar alınmıştır. Arşivde yer alan 8 Şubat 1946 tarihli belgeden anlaşıldığına göre Denizli İl İdare Kurulu üyesi olan Şükrü Süer, aynı zamanda Dokumacılar Kooperatifi Müdürlüğü görevini de yürütmeye çalışmıştır. Fakat işleri çoğaldığı için Buldan'dan ayrılamamış, Denizli'deki il idare kurulu toplantılarına katılamamıştır (BCA, 490.1.0.0/151.599.2,22.03.1948, s. 39). Bunun üzerine Şükrü Süer'in yerine bir başka üyenin getirilmesi uygun görülmüştür (BCA, 490.1.0.0/151.599.2,22.03.1948, s. 40). Aynı şekilde Çivril ve Tavas ilçelerinde de, parti ve belediye başkanlıkları tek kişinin üzerinde olduğu için gerekli düzenlemelerin yapılması istenmiştir (BCA, 490.1.0.0/151.599.2,22.03.1948, s. 60). 10.04.1948 tarihinde yapılan il kongresinde başkan seçilen Esat Kaymakçı, Divan üyeliğinde açılan azalığa sırası geldiği için başkanlıktan ayrılmış, yerine Hüsnü Örnek başkanlığa getirilmiştir. Hüsnü Örnek'in parti başkanı ve belediye başkanı olması, hem devlet işlerinin aksamasına neden olabileceği, hem de bu iki görevin bir şahısta toplanması uygun olmayacağı gerekçesi ile uygun görülmemiştir. Hüsnü Örnek, başkanlığa geldikten sonra diğer görevinden çekilmiştir. Yeniden açılan İl idare Kurulu Başkanlığı için 2.12.1949 tarihinde yapılan seçimde ise İl İdare Kurulu üyesi Şükrü Süer başkanlığa seçilmiştir (BCA, 490.1.0.0/151.600.1,17.01.1950, s. 8).

DP, ülke genelinde olduğu gibi Denizli'de de teşkilatlanmasına hız vererek başarılı sonuçlar almaya başlamıştır. CHP'de ise siyasi çekişmeler artmaya başlamıştır. CHP idare üyelerinden Hüseyin Ekseli, 4 Haziran 1946 tarihinde CHP Genel Sekreterliğine gönderdiği yazıda CHP'nin Çivril şubesinin henüz yeni kurulan bir partiye belediye seçimlerinde mağlup olmasını sindiremediğini belirterek, yapılan hataların yaklaşan milletvekili seçimlerinden önce giderilmesini istemiştir. Ayrıca Denizli’nin hiçbir köşesinde Demokrat ve Kalkınma Partilerinin teşekkül etmediğini, yalnız Çivril'de DP kurulmasındaki başlıca nedenin Başkan Mustafa Çorbacı'nın belediye seçimini kaybetmiş olmasından kaynaklandığını ifade etmiş̧tir (BCA, 490.1.0.0/449.1851.4,27.01.1948, s. 4). CHP İl İdare Kurulu Başkanı tarafindan 20 Ocak 1947 tarihinde CHP Genel Sekreterliğine gönderilen yazıda Çivril ilçesinden Hüseyin Ekseli imzasıyla genel sekreterliğe gönderilen mektup suretlerinin incelendiği belirtilmiş ve kısa bir açıklama yapılmıştır. Yapılan açıklamada Ekseli'nin kısa bir süre ilçe idare kuruluna getirildiği, fakat belediye seçimlerinde demokratlara söz ve fiilen hizmet ve yardım ettiğinin tespit edildiği belirtmiştir (BCA, 490.1.0.0/449.1851.4,27.01.1948, s. 1). 
CHP, bu dönemde yapılan seçimlerde, henüz karşısında güçlü bir DP teşkilatı olmamasına rağmen, köy muhtarı ve ihtiyar heyeti seçimlerine önem vermiş, önceki yıllarda parti tarafından aday gösterilmemiş olsalar bile halkın saydığı ve sevdiği, sağlam karakterli kişilerin seçilmesi yönünde çalışmalar yapmıştır. CHP'nin bu çalışmaları da olumlu neticeler vermiştir (BCA, 490.1.0.0/151.600.1,17.01.1950, s. 42). 4541 say1l kanun ile bu kanunun bazı maddelerini değiştiren 5046 sayılı kanun hükümlerine göre şehir ve kasabalarda 30 Mayıs 1947 tarihinde yapılan mahalle muhtarı ve ihtiyar heyeti seçimlerinde CHP aday göstermemiştir. İl merkeziyle, 7 ilçe ve beldelerinde belediye teşkilatı bulunan 12 kasaba ve bucakta mevcut 87 mahallede yapılan bu seçimde kazananların 71'i CHP'ye, 16 tanesi muhalefet partisine mensup üyelerden oluşmuştur. Netice itibarıyla CHP'ye mensup Denizli'deki köy ve kasabalarda bulunan muhtar sayıs1 478, DP mensubu muhtar sayısı ise 36 olarak belirlenmiştir (BCA, 490.1.0.0/151.600.1, 17.01.1950. s. 45).

CHP Denizli il idare teşkilatı, seçimlerin yaklaştığı bir dönemde, halkın memnuniyetini sağlamak için birtakım girişimlerde bulunmuştur. Denizli'de köyde yaşayan topraksız 152 aileye toprak verilmiş ve tapuları Vali Ahmet Demir tarafından teslim edilmiştir. Köylü bu durumdan çok memnun olmuş, yetkililer tarafindan toprak verilmesine devam edileceği ilan edilmiştir (Denizli'de 152 Aile Daha Toprak Sahibi Oldu, Cumhuriyet, 3 Ocak 1948, s. 3). CHP'nin bütün çabalarına rağmen mevcut olan rahatsızlık devam etmiş ve partiden kopmalar başlamıştır. Denizli CHP İl İdare Kurulu Başkanı Esat Kaymakçı tarafından 21 Ocak 1948 tarihinde CHP Genel Sekreterliğine gönderilen yazıda, Aydın ilinin CHP teşkilatına kayıtlı olup, Denizli'de ikamet eden ve yerli dokuma ticaretiyle uğraşan Hamdi Toksöz'ün partiden istifa ettiği bildirilmiştir. Toksöz'ün, Denizli'de kurulmuş olan DP mensuplarıyla sıkı temas halinde bulunduğu, bir kez de bu partinin il idare kurulu üyeliğine seçildiği belirtilmiştir (BCA, 490.1.0.0/449.1851.4,27.01.1948, s. 5). DP'ye katılımlar bununla da sınırlı kalmamıştır. Çal ilçe merkezinde Ahmet Kuran ve Selahattin Alp isimli şahıslar, CHP'ye kayıtlı iken istifa etmeden DP'ye üye olmuşlar ve fiili vazife alarak çalışmalarına devam etmişlerdir (BCA, 490.1.0.0/151.599.2,22.03.1948, s. 9). Ahmet Kuran ile Selahattin Alp'in partiden kayıtlarının silinmesine genel idare kurulunun 12.2.1948 günlü toplantısında karar verilmiştir (BCA, 490.1.0.0/151.599.2,22.03.1948, s. 7). CHP'den ayrilmalar 1950 seçimlerine kadar devam etmiş̧tir (İnan, 2005, s. 111). CHP'nin Denizli'deki ilk teşkilatından itibaren partide kayıtlı olan ve uzun yıllar il idare kurulu üyeliği yapan, 1938 yılındaki seçimde CHP milletvekili olarak Büyük Millet Meclisi'nde dört sene görev yapan Tahir Berkay da, CHP'den ayrılmıştır. 10 Nisan 1949'da DP il kongresinde il idare kurulu üyeliğine seçilen Berkay, 8 Nisan 1949 tarihinde eski Vali Cevat Ökmen ile birlikte Kayalık DP ocağına giderek, CHP aleyhinde konuşma yapmıştır. Konuşmasında DP'lilerle birlikte çalışacağını belirterek, partiye girdiğini ifade etmiştir (BCA, 490.1.0.0/575.2287.4, 27.06.1949, s. 7). Bunun üzerine kendisinden savunma talebinde bulunulmuştur. Tahir Berkay, Denizli il kuruluşuna hitaben yazdığı savunmasında, olayı doğrulamakla beraber, istifa etmeden karşı partiye geçişinin ve bu partide faal vazife almasının sebeplerini izaha lüzum görmediğini beyan etmiştir (BCA, 490.1.0.0/575.2287.4, 27.06.1949, s. 3). Çok geçmeden de partiden kaydı silinmiştir (BCA, 490.1.0.0/575.2287.4, 27.06.1949, s. 1).

Denizli'de CHP içinde partiden ayrılmaları önlemek ve muhalefet partisine karşı gerekli önlemlerin alınması için çalışmalara hız verilmiştir. Yapılan çalışmalarda partinin il bazında oturmuş fiziki bir düzeninin bulunmadığı anlaşılmıştır. Genel olarak halkevlerinden faydalanılamadığı, Buldan'da partinin kira ile tutulmuş küçük bir dükkân içinde çalışmakta olduğu (BCA, 490.1.0.0/1575.416.1, 08.07.1947, s. 5-7), kadınlar kolunun kurulması için bile yeterli binanın olmadığı tespit edilmiştir (BCA, 490.1.0.0/151.599.2,22.03.1948, s. 86). DP ise gücünü arttırarak büyümeye devam etmiştir. Arşivde yer alan bir belgede daha önceki yıllarda muhalefet partilerinin, teşkilatlarını genişletemedikleri ve tecrübesiz oldukları için faaliyetlerinin kısmen sınırlı olduğu, fakat daha sonraki yıllarda CHP'ye muhalif bütün unsurların çok fazla faaliyet gösterdiği belirtilmiştir. Belgeden anlaşıldığına göre basında birkaç partili gazete hariç, tek cephe halinde CHP aleyhine çalışılmış, muhalefette yer alan idareciler, şehirler ve köyler arası gezi, miting ve her türlü propaganda vb. faaliyetlerinde bulunmuşlardır. 1948 tarihinde Sarayköy, 
Buldan, Tavas, Acıpayam, Çivril ve Denizli il merkezinde DP genel başkan veya genel idare kurulu üyeleriyle civar illerden iştirak eden parti teşkilatı idarecilerin katıldığı mitinglerde CHP aleyhinde konuşmalar yapılmıştır (BCA, 490.1.0.0/151.600.1, 17.01.1950. s. 16). Denizli'de DP Başkanı Celal Bayar ile bir grup DP'linin yaptığı mitinglerden biri, Ekim 1948 tarihinde gerçekleşmiş, Celal Bayar yaptığı konuşmasında seçimin yenilenmesi konusu üzerinde durmuştur (Nazilli'de Müessif Bir Hadise, Cumhuriyet, 18 Ekim 1948, s.3). 17 Ekim 1948 tarihinde Denizli' de Çatalçeşme Parkında yapılan mitinge partili partisiz 1500 kişi iştirak etmiştir. Mitinge katılmak için gelen, Nazilli DP Başkanı Şevki Hasırcıoğlu, konuşmasında yeni bir seçim kanunu istediklerini, böyle bir kanun yapılmadığı takdirde sandık başına gitmeyeceklerini belirtmiştir. Babadă̆ bucağı DP Başkanı Zeki Mutçalı ise, yaptığı konuşmasında seçim kanunundan bahsetmiş, hâkimiyetin kayıtsız şartsız millete ait olması gerektiğini, iradenin tam manasıyla milletin arzusuna bırakılmasını istemiştir. Honaz DP Başkanı Nihat Bey, tek şef sisteminin manasız olduğunu belirterek, milletin feryadını duymayan iktidarın sözüne inanmayacaklarını, milletin arzularına uymayan bir seçim kanununun mevcut olduğunu, iktidar partisinin dürüstlükten ayrıldığını, seçim kanunu değişmediği takdirde katiyen seçimlere iştirak etmeyeceklerini, milletin iktidar partisinin yolsuzluğu yüzünden sefil düştüğünü ve bu vaziyet karşısında maddi ve manevi fedakârlık yaparak toplandıklarını ve icap ederse kilometrelerce daha gideceklerini söylemiştir. Daha sonra söz alan Refik Koraltan ise tek şef sisteminin olumsuzluklarına temas etmiştir (BCA, 30.1.0.0/66.410.2,19.10.1948, s. 4,5,7). Bu mitingden bir süre sonra Cumhurbaşkanı İsmet İnönü, Meclis Başkanı, Başbakan ve diğer bakanların da yer aldığı devlet erkânı, Denizli'yi ziyaret etmişlerdir (BCA, 490.1.0.0/151.600.1,17.01.1950, s. 15).

$\mathrm{Bu}$ arada Denizli'de faaliyet göstermek isteyen tek parti DP olmamıştır. CHP Aydın Bölgesi Müfettişi İzmir Milletvekili Dr. Hulki Cura tarafından, 16 Aralık 1948 tarihinde CHP Genel Sekreterliğine gönderilen yazıda, "Müstakil Türk Sosyalist Partisi" tarafindan Denizli’de dağıtılan beyannameden bahsedilmiştir. Cura, adı geçen partinin ne Aydın'da ne de bölge dâhilinde taraftarının ve üyesinin bulunmadığını bildirmiştir (BCA, 490.1.0.0/448.1846.2,16.05.1951, s. 4).

DP'nin Denizli'de yaptığı mitinglerden sonra, ağırlığını gün geçtikçe hissettirmeye başlaması ve seçimlerin yaklaşması, yetkililerin bazı tedbirler almasını gerekli hale getirmiştir. 23 Temmuz 1949 tarihinde CHP İl İdare Kurulu Başkanı Şükrü Süer tarafindan, CHP Denizli Seçim Kurulunun aldığı seçim tedbirleri ile ilgili olarak, CHP Genel Sekreterliğine bir yazı gönderilmiştir. Yazıda, parti içindeki olumsuzluklardan ve seçimin kazanılması için il idare kurulunun aldığ kararlardan bahsedilmiştir. Parti içinde tecrübeli şahsiyetlerin bulunması nedeni ile devlet idaresinde herhangi bir iş için eleman bulmakta güçlük çekilmediği, muhalefet partilerine karşı sağlam ve kuvvetli olunduğu, halkın büyük bölümünün de partinin ve hükümetin yanında bulunduğu belirtilmiştir. Fakat bütün bu olumlu duruma rağmen bazı tehlikelerden de bahsedilmiştir. Uzun seneler tek parti halinde devlet idare edildiği için, parti içinde şahsi ihtirasların belirdiği, muhalefetin çalışmaları karşısında aynı şahsi ihtirasların eskisinden daha fazla gündeme geldiği ifade edilmiştir. 1946 seçimlerinden sonra, genç ve makam sahibi partililerin, partiden ayrılarak şahsi teşebbüste bulunduklarına ve muhalefet partiye geçtiklerine dikkat çekilmiştir. 1946 seçimlerinde gerçekleşen bu durumun muhalefetin zayıflı̆̆ tecrübesizliği ve teşkilatını her tarafta kuramamış olmasından ve hükümetin çabaları sayesinde bertaraf edildiği, fakat buna rağmen parti içinde bazı kimselerin rengini belli etmeyerek, iki taraflı faaliyette bulunduklarına dikkat çekilmiştir. Ayrıca il dâhilinde kanunen çıkabilecek milletvekili sayısının çok üstünde aday başvurusu olabileceği, bu nedenle milletvekilliğine liyakatli olanların tespit edilerek, seçimlerde kendi illeri dâhilinde adaylıklarını koymalarının sağlanması istenmiştir. Parti adaylarının seçiminde değerli şahsiyetlerin hariç bırakılma tehlikesinin önlenmesi ve seçilebilecek adaylar hakkında il idare kurullarının görüşlerinin alınmasının sağlanmasının gereği üzerinde de durulmuştur (BCA, 490.1.0.0/365.1534.2,23.07.1949, s. 1-3).

Partinin gençlere değer vermesi de diğer öneriler arasında yer almıştır. Bütün bunlara ilaveten memurların bazı olumsuz tavırlarından bahsedilmiş, gerekirse bazı memurların tasfiye 
edilmesi gerektiği bildirilmiştir. Adliye mensuplarından bazılarının, parti aleyhine karar verdikleri için, partinin çok zarar gördüğü, seçim kanununa göre adliye mensubu memurların sandık başlarında bulunacakları için gerekli önlemlerin alınması ve adaletin tarafsızlıkla işlemesinin sağlanması üzerinde durulmuştur. Parti aleyhine söylemleri olan bazı öğretmenler hakkında yapılan şikâyetlerin gizli olarak soruşturulması, gerekirse söz konusu öğretmenlerin başka yerlere nakledilmeleri gibi bazı tedbirlerin alınmasının önemi üzerinde durulmuştur. Partinin desteklemesiyle iş başına gelen belediye teşkilatının ise seçim bittikten sonra parti ile olan ilgilerini gevşettikleri, bu durumun ise olumsuzluklara neden olduğu ifade edilmiştir. Parti kongrelerinde dileklerin dikkate alınmadığı, bunun da kırgınlık oluşturduğuna dikkat çekilerek, bütçe ve bazı dileklerin yerine getirilmesi için belediyelerin gelir bakımından desteklenmesinin gerektiği belirtilmiştir. Propaganda yönünden de partinin zayıf kaldığına işaret edilerek, her zaman için istifade edilebilecek süratli nakil vasıtaları ile haftanın müsait günlerinde ilçeler arası gezilerin yapılabileceği, bundan da büyük faydalar sağlanacağı ifade edilmiştir. Partinin halka hitap edecek gazete ve mecmualar çıkarması, milli varlığa zarar verecek şekilde yapılan neşriyat ve iftiralara vaktinde cevaplandırılarak, meydana getirilmiş olan menfi zihniyetin düzenlenmesine çalışılmasının gerekli olduğunun altı çizilmiştir. Karşı partilerin mitinglerde veya toplantılarda söyledikleri sözlerin, çok mühim olanlarına radyo vasıtasıyla veya broşürlerle ve toplantılarla cevap verilmesi ve muhalefetin taşkınlıklarının ara sıra dizginlenmesi gerektiği belirtilmiştir. Propaganda konusunda milli duyguları canlandıracak tarihi filmlerin yanı sıra, devletin cumhuriyet devrinden önceki durumu ile bugününü mukayese imkânı verecek yenilikleri canlandıran filmlerden de yararlanılabileceği belirtilmiştir. Halkı etkileyen görevlerde çalışan şahısların seçimlerde ve propaganda hususlarında mühim rol oynadıkları görüldüğü için, bu kişilerin seçimlerinde ve istihdamlarında dikkatli olunması, kötü temayülü hissedilenlerin vazifelerine son verilmesi gerektiği belirtilmiştir (BCA, 490.1.0.0/365.1534.2,23.07.1949, s. 48).

CHP İl İdare Kurulu Başkanı Şükrü Süer tarafından gönderilen yazıda Denizli’de mevcut parti teşkilatlarından da bahsedilmiştir. Yazıda DP'nin teşkilatının mevcut olduğu, diğer partilerin teşkilatının olmadığı, ildeki DP'li parti idarecilerinin her bakımdan zayıf olduğu, bu sebeple de halen pasif durumda oldukları belirtilmiştir. Bununla beraber muhaliflerin sessizce genişleme faaliyetlerine başladıklarının görüldüğü ifade edilmiştir. Sayı olarak zayıf olan DP'lilerin, halk üzerinde manevi bask1 yaptıkları, en zayıf bulundukları muhitlerde bile mevcudiyetlerini hissettirmek için programlı bir surette çalıştıkları ve çok para harcadıkları ifade edilmiştir. Ayrıca DP mensuplarının kendi aralarında çıkan en küçük bir anlaşmazlıkta dağılma işaretleri gösterdiği, milletvekili adayı olarak gösterilmeyen yerli DP mensuplarının kendi partilileri aleyhine durum alacakları göz önünde bulundurularak, bu durumdan faydalanabileceği ve DP'lilerin aralarına itimatsızlı sokarak, zayıflatılabileceği ifade edilmiştir. Seçim günü sandık başında görevlendirilecek memurların, daha önceden haklarında hükümetçe sıkı bir inceleme yapılarak sabıkalı olup olmadıklarının araştırılması, dürüst ve namuslu vatandaşların sandık başına görevlendirilmesinin temini ve seçim merkezlerinde kötü niyetli kimselerin ve grupların halk üzerinde baskı yapmasına izin verilmemesi için gerekli tedbirlerin alınmasının gereği üzerinde durulmuştur. CHP parti teşkilatı ve nüfuzlu partililer arasında çıkabilecek anlaşmazlıkların da seçimin kaybedilmesine neden olacağı bu nedenle bu hususa özellikle dikkat edilmesi tavsiye edilmiştir. CHP mensuplarının iyi hareketlerinin, hükümetin iyi ve adaletli çalışmalarının, CHP aleyhine yapılacak propaganda ve neşriyatın vaktinde cevaplandırılıp halkın aydınlatılmasının sağlandığ 1 takdirde seçimi kazanmanın mümkün olduğu belirtilmiştir (BCA, 490.1.0.0/365.1534.2,23.07.1949, s. 8-9).

CHP Denizli il kongresi 28.12.1949 tarihinde toplanmış, kongreye Denizli milletvekilleri Dr. Behçet Uz, Hulusi Oral, Dr. Hamdi Berkman, Cemil Çalgüner, Naili Küçüka, Kemal Cemal Öncel ve Abidin Ege de katılmıştır. İl İdare Kurulu Başkanı Şükrü Süer, kongrede yaptığı konuşmasında başta tarım, kültür, bayındırlık, ekonomi ticaret ve endüstri olmak üzere hemen hemen her alanda kalkınma ve gelişme gösterdiklerini dile getirmiştir. Bununla birlikte CHP'nin başarılarını çekemeyen muhalif partilerin, gerçekle taban tabana zıt yönlerdeki söylemlerinin 
parti iftiralarının bir neticesi olarak görülmesi gerektiğini belirtmiştir. Konuşmasında yeni bir seçim kanununun hazırlanarak, Meclis'e sunulduğunu da dile getirmiştir. Kongrede CHP'nin Denizli ve çevresinde 8 ilçe, 10 resmi ve 32 itibari bucak, 88 mahalle, 4 semt ve 427 köy ocağ 1 olmak üzere toplam 568 kademesi bulunduğu ifade edilmiştir. 1949 tarihli kongrede CHP'ye kayıttl üye sayılarına da yer verilmiştir. Buna göre Denizli'de 12.307, Acıpayam'da 6859, Buldan'da 1395, Çal'da 7347, Çivril'de 3664, Tavas'ta 4492, Sarayköy'de 2949 ve Güney'de 1940 üye olmak üzere toplam 40.653 kişi CHP'ye üyedir. 1948 yılında CHP'nin Denizli' deki üye sayısı ise $36.545^{\prime}$ tir.Son bir yılda 4108 üye artış1 sağlanmıştır (BCA, 490.1.0.0/151.600.1,17.01.1950, s. 4,6,10,11).

CHP yöneticilerinin, partiye katılımların arttığını söylemelerine karşın, DP'ye üye olanların sayısının da artması, iki parti arasındaki siyasi mücadelenin şiddetinin, seçim günü yaklaştıkça artmasına neden olmuştur. Denizli Orman İşletmesi Bölge Kâtibi İzzet Erdem, 14 Ekim 1949 Cuma günü Denizli Musaağa Mahallesi parti ocak binası yanındaki kahvede, yanında DP İl İdare Kurulu üyeleri olduğu halde, CHP'nin şahsiyeti maneviyesine ve parti mensuplarına kötü sözler söylediği için burada bulunan parti mensupları tarafından ilgili yerlere şikâyet edilmiştir. Şikâyette bulunanlar, İzzet Erdem'in işlediği suçun doğrudan doğruya CHP şahsiyeti maneviyesine hakaret sayıldığını belirterek, parti tarafindan ilgili şahsa dava açılması talebinde bulunmuşlardır (BCA, 490.1.0.0/459.1887.4, 24.11.1950, s.8). Fakat CHP Genel Sekreterliğinden 24.11.1949 tarihinde Denizli CHP İl İdare Kurulu Başkanlığına gönderilen yazıda, dava açılması için yapılan hakaretinin üç veya daha fazla kimse yanında söylediğinin ispat edilmesi gerektiği bildirilmiştir (BCA, 490.1.0.0/459.1887.4, 24.11.1950, s.7). Denizli CHP İl İdare Kurulu Başkanı Şükrü Süer'in, 5 Ocak 1950 tarihinde CHP Genel Sekreterliğine gönderilen yazıda ise, partinin manevi şahsiyetine sözle hakaretten dolayı hakkında kanuni takibat yapılması için gerekli olan asgari üç şahidin var olduğu fakat bu kişilerin DP il idare kurulu üyesi olduğu belirtilmiştir. Ayrıca Orman İşletme Kâtibi İzzet Erdem'in partiye gelerek, çeşitli sebeplerden dolayı bir hata işlemiş olabileceğini, ama hiçbir zaman kötü bir niyet beslemediğini, bilmeyerek işlenmiş kusurunun affını istediği bildirilmiştir. Esas gayenin gerçekleştiği ve mahkemeyi kazanabilmek için emin üç şahidin temin edilmesinin de mümkün olmadığ 1 belirtilerek, dava açmaktan vazgeçilmiştir (BCA, 490.1.0.0/459.1887.4, 24.11.1950, s.6). Fakat iki parti arasında sular durulmamıştır. 4 Mayıs 1950 tarihinde CHP Genel Sekreterliğine acele olarak gönderilen telgrafta DP Kâtibi Nuri Seçginer'e, CHP'ye karşı söylediği sözlerden dolayı parti adına dava açılması istenmiştir (BCA, 490.1.0.0/459.1887.4, 24.11.1950, s. 5).

\section{14 Mayıs 1950 Milletvekili Seçimleri}

Seçim yasasının kabulünden kısa bir süre sonra partiler seçim kampanyalarına başlamışlardır. Seçim kampanyalarında CHP, tarım reformundan ve özel teşebbüs imkânlarından bahsetmiş, DP ise siyasal ve ekonomik daha fazla hürriyet, daha çok özel teşebbüs, işçiler için grev hakk1 konuları üzerinde durmuştur (Lewis, 2000, s. 311). Partilerin seçim listelerine bakıldığında CHP'de milletvekili olanların \% 40'ı yeni listede yer almamış, listede avukat, idareci, iktisatçı, maliyeci, doktor, tüccar, eğitimci, çiftçi, asker, belediyeci, yüksek mimar gibi meslek mensupları ağırlıklı olarak hemen her kesimden kişiler yer almıştır. DP ise listesini genellikle avukat, idareci, tüccar, doktor, çiftçi, asker, eğitimci ve yüksek mühendislerden oluşturmuştur (Eraslan, 2004, s. 546).

CHP ve DP bütün yurtta, MP 22 ilde ve MKP de yalnızca İstanbul'da seçime katılmıştır (Koçak, 2002, s. 192). 14 Mayıs 1950 genel seçimlerinin sonunda oyların tasnifleri devam ederken bile DP ile diğer partilerin adayları arasında oldukça büyük bir fark meydana gelmiştir (Tasnif Devam Ederken Demokrat Partinin Seçimi Kazandığ İller, Yeni İstanbul, 16 Mayıs 1950, s.1). 15 Mayıs 1950 tarihinde Denizli'de tasnifi biten sandıkların oyların üçte ikisini DP almıştır. Buna göre DP 4765, CHP 1635 oy elde etmiştir (Son Dakika, Milliyet, 15 Mayıs 1950, s.5). DP, Denizli başta olmak üzere birçok ilde seçimlerde üstünlük sağlamıştır (DP, Dün Gece Yarısı 41 Vilayette 370 Mebusluk Kazanarak Ekseriyeti Ald1, Milliyet, 16 Mayıs 1950, s.1). Katılım oran1 
\%89,3 olarak gerçekleşmiş, 8.905.743 seçmenin 7.953 .055 'i oyunu kullanmış ve toplam 487 milletvekili seçilmiştir. Bu seçimlerde ülke genelinde DP 4.241 .393 oy alarak \%53,3 oy oranı ile 408 milletvekili, CHP 3.176.561 oy alarak \%39,9 oy oranı ile 69 milletvekili çıkarmayı başarmıştır. MP, 250.414 oy alarak \%3,1 oy oranı ile 1 milletvekili çıkarmayı başarırken, bağımsızlar 383.282 oy alarak \%4,8 oy oranı ile 9 milletvekilliği kazanmışlardır (Koçak, 2002, s. 193). CHP, ülkenin daha kalkınmış olan Batı bölgesinde üstünlük sağlayamamıştır. Kazandığı bütün vilayetler, Ankara'nın doğusunda yer almış ve bu büyük ölçüde az gelişmiş bölgeler olmuştur (Zürcher, 2015, s. 318).

Yapılan seçim sonucunda Denizli'de DP'den kazanan adaylar Ali İhsan Sabis, Refet Tavaslıoğlu, Fikret Karabudak, Hüsnü Akşit, Ali Çobanoğlu, Dr. Mustafa Gülçigil, Fikret Başaran, Eyüp Şahin olmuştur (BCA, 30.10.0.0/77.510.2, 18.05.1950, s. 2; DP Dün Gece Yarıs1 41 Vilayette 370 Mebusluk Kazanarak Çoğunluğu Aldı, Milliyet, 16 Mayıs 1950, s. 5; İnan, 2005, s. 117).

Seçimlerden sonra iki parti arasında sular durulmamıştır. 24 Kasım 1950 tarihinde CHP Il İdare Kurulu Başkanı Şükrü Süer tarafından, CHP Genel Sekreterliğine gönderilen yazıda Bekilli'den Mehmet Peker'in yazdığı bir mektupta birçok partililerin tutuklandığına dair bilgi alındığı belirtilmiştir. Bunun üzerine durum, Çal İlçe İdare Kurulundan sorulmuştur. Çal İdare Kurulu'ndan alınan cevapta Bekillili hiçbir partilinin tutuklanmadığı, fakat 20 kadar parti mensubunun sahte zabıtlarla mahkemeye verildiği öğrenilmiş ve gerekli tedbirler alınmıştır (BCA, 490.1.0.0/459.1887.4, 24.11.1950, s.2).

\section{Sonuç ve Öneriler}

Bir taşra kenti olan Denizli'de halkın savaş yıllarında ekonomisi bozulmuş, halk ise bozulan ekonomik durumunu düzeltmek için yöneticilerden birtakım taleplerde bulunmuştur. Fakat ülkenin içinde bulunduğu durumdan dolayı, sorunların büyük bölümü çözülememiştir. İkinci Dünya Savaşı sonrasında yapılan ilk genel seçimler 1946 yılında, açık oy, gizli sayım ilkesine ve çoğunluk sistemine göre yapılmıştır. Yeni kurulan bir parti olan DP'nin Denizli'de, parti teşkilatını tamamlayamamasının bir sonucu olarak, seçilen milletvekillerinden bir bağımsız aday hariç, hepsi CHP'li adaylardan oluşmuştur.

Seçimlerden sonra DP'nin Denizli'de hızlı bir şekilde teşkilatlanmaya başlaması, CHP'nin tedbirler almasını gerekli hale getirmiştir. Öncelikle parti yönetiminde birden çok görevi olan yöneticilerin, daha verimli çalışmaları için görev yükleri azaltılmıştır. Daha sonra Denizli CHP il örgütü tarafından düzenli olarak toplantılar yapılmaya çalışılmış, hatta bu toplantılara Denizli milletvekillerinin katılımı sağlanmıştır. Fakat milletvekillerinin bu toplantılara katılmasının, 1950 seçim sonuçlarına bakıldığında, büyük bir etki oluşturduğunu söylemek pek mümkün değildir. Bununla birlikte CHP'nin yenilgisini, tek bir nedene bağlamak da doğru değildir. Çünkü Acıpayam'da olduğu gibi CHP'li belediyelerinin çalışmalarından memnun olmayan önemli bir kesim bulunmaktadır. Uzun yıllar iktidarda olmasına rağmen CHP'nin hala Denizli' de il bazında oturmuş, fiziki bir düzeninin bulunmaması da önemli bir eksikliktir. Bütün bunlara ilaveten CHP il teşkilatında yaşanan siyasi çekişmeler sonrasında partiden ayrılmaların meydana gelmesi de CHP'nin zayiflamasına neden olmuştur. Siyasi gücü olan kişilerin CHP'den ayrılarak, DP örgütü içinde yer almalarının, bu kişileri benimseyen önemli bir kesimin de tarafinı değiştirmesine neden olacağını varsaymak pek de yanlış sayılmaz. 1950 seçimlerinin yaklaştığı günlerde, CHP Denizli il teşkilatında yapılan bir toplantıda seçimlere yönelik bazı tedbirlerin alınmasının istenmesi, aslında güçlü bir muhalefete karşı alınması istenen tedbirler olarak değerlendirilebilir. Seçimlerden önce miting yapmak için Denizli'ye gelen DP Genel Başkanı Celal Bayar'ın ardından, Cumhurbaşkanı İsmet İnönü’nün Denizli halkı ile görüşmek için gelmesi, her iki partinin Denizli'de ciddi bir siyasi mücadeleye girişeceğinin işaretidir. Bununla birlikte yine aynı toplantıda DP'nin sayıca az, yöneticilerinin ise zayıf olduğunun belirtilmesi, CHP tarafından rakibin fazla dikkate alınmadığını göstermektedir. Üstelik CHP yöneticilerinin 
partilerindeki üye sayılarına bakarak, güçlü olduklarını düşünmeleri, aslında birtakım olumsuzlukları göremediklerini ya da DP'nin gücünü gözden kaçırdıklarını da göstermektedir.

CHP'nin rakibini küçümsemesi ya da rakibinin gücünü gözden kaçırması, Denizli halkının sorunlarının tespit edilmiş olsa bile çözümleme kısmında yetersiz kalınması, CHP'li bazı yöneticilere karşı memnuniyetsizlik, CHP'de yaşanan siyasi çekişmeler ve partiden ayrılmalar, genel seçimler öncesinde CHP'nin dezavantajları olarak değerlendirilebilir. Fakat aynı zamanda 1950 seçimlerinde oluşan farkın sadece CHP'nin dezavantajlarına bağlamak da doğru olmaz. Çünkü DP'nin kurulduktan sonra bütün gücü ile Denizli'de teşkilatlanması ve parti yöneticilerinin halkla bir araya geldiklerinde sergiledikleri samimi davranışları, DP'ye halk nezdinde büyük bir avantaj kazandırmıştır.

1950 yılına kadar olan dönemde Denizli'de CHP ve DP arasında büyük bir rekabet ve siyasi çekişme yaşanmıştır. 1950 yılında yapılan seçimleri DP büyük farkla hem Denizli'de hem de Türkiye genelinde kazanmıştır. Halkın büyük çoğunluğu, DP'yi kurtarıcı bir siyasi parti olarak görmüş, seçimini yeni kurulan partiden yana kullanmıştır. Fakat seçimlerden sonra bile Denizli' de iki siyasi parti arasındaki anlaşmazlığın devam etmesi, CHP'nin iktidarı kaybetmesine rağmen, güçlü bir muhalefet yapacağını göstermiştir.

\section{Kaynakça}

Acıpayamın Dertleri, Tan, 5 Haziran 1949, s.4.

Aydın, M. (2004). İkinci Dünya Savaşı ve Türkiye 1939-1945. B. Oran (Ed), Türk Dış Politikası Kurtuluş Savaşından Bugüne Olgular, Belgeler, Yorumlar (ss. 399-476). İstanbul: İletişim Yayınları.

Başbakan Diyor ki, 1950’den Evvel Yeni Seçim Yapılmayacak, Akşam, 4 Nisan 1948, s.2.

BCA, CHP Denizli İl İdare Kurulu'nun Aldı̆̆ı Seçim Tedbirleri, 490.1.0.0/365.1534.2,23.07.1949.

BCA, CHP Denizli İl İdare Kurulu'nun Kongre Nutukları Ve Çalışma Raporları, 490.1.0.0/151.600.1, 17.01.1950.

BCA, CHP Denizli Teşkilatı'ndan İstifa Edenlerin Listelerinin Genel Sekreterliğe Gönderildiği, 490.1.0.0/449.1851.4,27.01.1948.

BCA, Demokrat Parti Genel Başkanı Celal Bayar Ve Arkadaşlarının Acıpayam ve Denizli'de Yaptıkları Konuşma, 30.1.0.0/66.410.2,19.10.1948.

BCA, Demokrat Parti'nin 14 Mayıs 1950 Gününü Denizli'de Kutladığı, 490.1.0.0/448.1846.2,16.05.1951.

BCA, Denizli Eski Milletvekili Tahir Berkay'ın CHP'den İstifa Etmeden Demokrat Parti'ye Geçişi İle İlgili Yazışmalar, 490.1.0.0/575.2287.4,27.06.1949.

BCA, Denizli İl İdare Kurulu'nun CHP Genel Sekreterliği İle Parti Yönetimi Ve Seçim Yazışmaları, 490.1.0.0/151.599.2, 22.03.1948.

BCA, Denizli İli Teftiş Raporları, 490.1.0.0/1575.416.1, 08.07.1947.

BCA, Denizli Milletvekili Cemil Çalgüner'in Denizlili Çiftçilere Yardım Yapılması İle İlgili Sözlü Soru Önergesi, 30.1.0.0/53.314.5,21.04.1947.

BCA, Denizli Milletvekilliklerine Seçilen Sekiz Kişinin Seçim Tutanağının Sunulduğu, 30.10.0.0/77.510.2, 18.05.1950.

BCA, Denizli Vilayetinin 1945 Y1lı Teftiş Raporunun Genel Sekreterliğe Sunulduğu, 490.1.0.0/641.123.1,14.01.1946. 
BCA, Denizli'de Demokrat Partililerin CHP'ye Hakarette Bulunduğu, 490.1.0.0/459.1887.4, 24.11.1950.

Bizim İçin Esas Seçimlerin Emniyet Altına Alınmasıdır, Son Posta, 13 Aralık 1948, s.1.

Boratav, K. (2002). İktisat Tarihi (1908-1980). Türkiye Tarihi 4 Çağdaş Türkiye 1908-1980297380 İstanbul: Cem Yayınevi.

C. Bayar Antalya'da, Tan, 6 Mart 1949, s.7.

Demokrat Parti Kongresi, Vakit, 8 Ocak 1947.

Demokrat Parti Kongresinde Neler Görüşülecek, Vakit, 4 Ocak 1947, s.3.

Demokrat Partinin Adapazar1 Mitinginde, Son Posta, 4 Ekim 1948, s.7.

Demokratlar Gittikçe Sabırsızlanıyor, Cumhuriyet, 6 Ocak 1948, s.3.

Demokratlar ve Genel Seçim, Gece Postası, 22 Ağustos 1948, s.1.

Denizli, Tan, 12 May1s 1949, s.4.

Denizli'de 152 Aile Daha Toprak Sahibi Oldu, Cumhuriyet, 3 Ocak 1948, s.3.

DP Seçime Girseydi Milli İradenin Tecellisini Geciktirirdi, Son Posta, 10 Ekim 1948, s.1.

DP, Dün Gece Yarısı 41 Vilayette 370 Mebusluk Kazanarak Çoğunluğu Aldı, Milliyet, 16 Mayıs 1950, s.5.

DP, Dün Gece Yarıs1 41 Vilayette 370 Mebusluk Kazanarak Ekseriyeti Aldı, Milliyet, 16 Mayıs 1950, s.1.

DP'deki Anlaşmazlıklar, Yeni Sabah, 10 Şubat 1948, s.1.

Eraslan, C. (2004). Atatürk’ten Sonra Türkiye'nin İç Politikası. Türkiye Cumhuriyeti Tarihi II, (ss. 519-632). Ankara: Can Reklamevi Basın Yayın Ofset Matbaacılık.

Hale, W. (2003). Türk Dış Politikası 1774-2000. İstanbul: Arkeoloji ve Sanat Yayınları.

Hayat Pahalılığ ve CHP, Cumhuriyet, 9 Ocak 1948, s.1.

Hayat Pahalılığına Karşı Cezri Tedbirler Alınıyor, Tan, 17 Nisan 1949, s.1.

https://www.yenisafak.com-1946/denizli-ili-secimsonuclari, (Erişim Tarihi:22.10.2020).

Hükümetle Halk Partisi Arasında İhtilaf mı Var?, Cumhuriyet, 7 Ocak 1948, s.4.

İdari Zihniyet Değişiyor, Tan, 9 Mart 1949, s.1.

İktidara Düşen İlk Vazife Umumi Seçime Gitmektir, Son Posta, 22 Ekim 1948, s.7.

İlk Hedef Namuslu Bir Seçimdir, Son Posta, 9 Aralık 1948, s.1.

İnalcık, H. (2009). Doğu Batı Makaleler I. Ankara: Doğu Batı Yayınları.

İnan, A. (2013). Atatürk Hakkında Hatıralar ve Belgeler. İstanbul: Türkiye İş Bankası Kültür Yayınları.

İnan, S. (2005). CHP Müfettişi Cemal Karamuğla'nın Raporları Işı̆̆ında Bir Taşra Kenti Olan Denizli’de 1950 Seçimleri ve Gösterdikleri. Atatürk Dergisi, 4(3), 103-124.

Karabulut, U. (2014). Davetsiz Misafiri Beklerken İkinci Dünya Savaşı Türkiye'sinde Pasif Güvenlik Önlemleri (1939-1940). Çă̆daş Türkiye Tarihi Araştırmaları Dergisi, 14(28), 199223.

Karpat, K. H. (2009). Osmanlı'dan Günümüze Kimlik ve İdeoloji. İstanbul: Timaş Yayınları.

Karpat, K. H. (2010). Osmanlı'dan Günümüze Asker ve Siyaset. İstanbul: Timaş Yayınları. 
Koçak, C. (2002). Siyasal Tarih (1923-1950). Türkiye Tarihi 4 Çağdaş Türkiye 1908-1980, 127 211, İstanbul: Cem Yayınevi.

Koçak, C. (2009). Geçmişiniz İtinayla Temizlenir. İstanbul: İletişim Yayınları.

Koçak, C. (2015). Türkiye'de Milli Şef Dönemi (1938-1945). C.1, İstanbul: İletişim Yayınları.

Koçak, C. (2016). Tek Parti Cumhuriyet ve Şefler. İstanbul: İletişim Yayınları.

Lewis, B. (2000). Modern Türkiye’nin Doğuşu. Ankara: Türk Tarih Kurumu Basımevi.

Memur Kadroları İçin Mühim Bir Tamim, Cumhuriyet, 9 Ocak 1948, s.1.

Millet Partisi Program ve Tüzüğünü Hazırladı, Son Telgraf, 5 Temmuz 1948, s.1.

Muhalefet H. Partisinin Kararından Memnun, Cumhuriyet, 15 Ocak 1948, s.1.

Nazilli’de Müessif Bir Hadise, Cumhuriyet, 18 Ekim 1948, s.3.

Nutkun Metni, Cumhuriyet, 18 Ocak 1948, s.1.

Oran, B. (2004). 1939-1945: Savaş Kaosunda Türkiye, Göreli Özerklik-2. B. Oran (Ed), Türk Dış Politikası Kurtuluş Savaşından Bugüne Olgular, Belgeler, Yorumlar (ss. 387-398). İstanbul: İletişim Yayınları.

Ortayl1, İ. (2018). Türkiye’nin Yakın Tarihi. İstanbul: Pasifik Ofset Ltd. Şti.

Pahalılık Mitingi Dün Sabah Yapıld1, Tan, 9 Mayıs 1949, s.1.

Seçim Bölgelerindeki Muhabirlerimizin Telgrafları, Son Posta, 18 Ekim 1948, s. 7.

Son Dakika, Milliyet, 15 Mayıs 1950, s.5.

Sovyetlerin Talepleri, Cumhuriyet, 29 Haziran 1945, s.1.

Şen, C. (2019). Demokrat Parti Döneminde Denizli'de Siyasal Hayat (1950-1960) (Yayınlanmamış yüksek lisans tezi). Ağrı İbrahim Çeçen Üniversitesi, Ağrı.

T.C. Cumhurbaşkanlığı Devlet Arşivleri Başkanlığı Cumhuriyet Arşivi (BCA)

Tasnif Devam Ederken Demokrat Partinin Seçimi Kazandığı İller, Yeni İstanbul, 16 Mayıs 1950, s.1.

TBMM Albümü (1920-2010), TBMM Basın ve Halkla İlişkiler Müdürlüğü Yayınları, Ankara: Gökçe Ofset Matbaacılık Limited Şirketi.

Tekeli İ. ve İlkin S. (2013). Dış Siyaseti ve Askeri Stratejileri ile İkinci Dünya Savaşı Türkiye'si. C.I, İstanbul: İletişim Yayınları.

Tellal, E. (2004). SSCB İle İlişkiler. B. Oran (Ed), Türk Dış Politikası Kurtuluş Savaşından Bugüne Olgular, Belgeler, Yorumlar (ss. 499-521). İstanbul: İletişim Yayınları.

Turgut, H. (2005). Atatürk'ün Sırdaşı Kılıç Ali'nin Anıları. İstanbul: Türkiye İş Bankası Kültür Yayınları.

Yeni Parti, Cumhuriyet, 2 Haziran 1945, s.1.

Zürcher, E. J. (2015). Modernleşen Türkiye’nin Tarihi. İstanbul: İletişim Yayınları.

\section{ETIKK ve BİLIMSEL İLKELER SORUMLULUK BEYANI}

$\mathrm{Bu}$ çalışmanın tüm hazırlanma süreçlerinde etik kurallara ve bilimsel atıf gösterme ilkelerine riayet edildiğini yazar beyan eder. Aksi bir durumun tespiti halinde Afyon Kocatepe Üniversitesi Sosyal Bilimler Dergisi'nin hiçbir sorumluluğu olmayıp, tüm sorumluluk makale yazarlarına aittir. 